\title{
Features of aggression regarding homeless children
}

\author{
Lect. Univ. dr. Mihaela Luminița Sandu \\ “Ovidius" University of Constanta, Romania \\ mihaela_naidin@yahoo.com \\ Prof. univ. dr. habil. Mihaela Rus \\ "Ovidius" University of Constanta, Romania \\ psiholog_m@yahoo.com
}

\section{Lect. univ. dr. Ciprian Vasile Rus}

"Ovidius" University of Constanta, Romania

\begin{abstract}
Starting from the fact that man is a social being and the reality that teen, street child, living among people belonging to the same social environment, acting through a set of ways the environment, relationships with others, he must form a proper attitude and prosocial behavior. Respect individuality, training and development in line with its own development guidelines are necessary conditions in the educational process. Street children are those who are deprived of all monitoring and control, those who are exposed to overcrowding, hunger, cold and different risks. Due to their physical and emotional fragility, they are among the first victims of aggression. Their adaptation to life on the road conditions allow them to survive in a context where no professional skills, no money, no shelter and are likely to be exploited, physically and sexually abused. Survival in the street becomes possible through group membership, learn various skills in which they are intended to provide a form of income, their improvised shelters, most often in the channels and / or staircase, he organized a program day. They learn how to conduct profitable activities, limit their definition as legitimate and how to avoid being arrested or convicted, usually know that nothing happens to be minors.
\end{abstract}

Keywords. features of aggression, street children, homeless children

\section{Introduction}

The causes of this phenomenon are extremely complex, interlacing individual factors and social, economic and material factors that achieve cumulative effects that increase the proportion of the phenomenon. The consequences are quite serious: behavioral disorders, aggression, violence, deaths, embolism, sexual abuse, lack of moral and cultural norms.

Poverty, strife and violence in the family, to which is added the disorganization of the family are the main determinants and implicitly, causes that led to the arrival of children on the street. The overwhelming majority of children come from a disorganized and tense family environment, dominated by quarrels between parents and abuse directed at them and their siblings or brothers. 
They found the solution of the oppressive and insecure situation they were in, in the escape action from that environment felt hostile. The means of escape was the escape from home.

Even if between the moment of the awareness of the conflict by the children and the time of the actual escape from home, in many cases a long period elapses, the escape of children who were found on the street is not the result of a well-established plan, but rather, externalizing the self-defense instinct.

According to Vasile Preda (1981), "the factors of a family nature, involved in the cumulative multifactorial etiology of juvenile delinquency are the following: the" cold - indifferent "attitude of the parents, the" tyrannical "attitude of the parents, the conflict atmosphere, the disturbances of the moral climate of family, disorganization of the family - viewed from the angle of the disturbing factors and of the dysfunctional climate that determined it, with their repercussions on the ambivalent or discordant socialization of minors and young people.

\section{Research methodology}

The present paper aims to highlight the manifest behaviors of aggression in street children, as well as to highlight the particularities of self-esteem, self-image and social hostility in street children.

Starting from the objectives specified above, I have tried to demonstrate that self-esteem and low self-image lead to the manifestation of aggressive behavior but also that, in the street children who express a high degree of social hostility, aggressive behaviors appear.

According to the purpose, to illustrate the particularities of aggression in street children, the study was carried out at the "Day and night shelter for street children", Constanta.

There are also adolescents between the ages of 14-18, girls and boys, schooled or not, who come either from organized or disorganized families. The research was carried out on a group of 80 subjects, who frequent or live in this shelter.

After analyzing the data, the respondents almost always exhibit aggressive behavior, which is also influenced by the social environment and the living conditions with which they interact. The hostile behavior manifested by street children is characterized by negativity, verbal hostility, irritability, suspicion, assault, resentment and general hostility.

As shown in Table 1, there is a significant negative relationship between aggressive behavior and family type $(\mathrm{r}=-0.45, \mathrm{DF}=3, \mathrm{p}<0.001)$, which means that subjects who frequently exhibit aggressive behavior disorganized families. There is also a significant negative relationship between the aggressive behavior and the hostility of the subjects $(r=0.48, D F=2, p<0.001)$. The more aggressive the behavior manifests, the more hostile the subjects have high on inventory scales.

The correlation between family type and hostility manifested is -0.96 (significantly negative), which highlights that subjects from disorganized families exhibit more frequent hostile behavior. 
Table no. 1. Correlations: "Grid for aggressive behavior observation," Family type "and" Hostility inventory"

\begin{tabular}{|l|l|l|l|l|}
\hline & & $\begin{array}{l}\text { Aggressive } \\
\text { behavior }\end{array}$ & Family type & $\begin{array}{l}\text { Hostility } \\
\text { inventory }\end{array}$ \\
\hline $\begin{array}{l}\text { Aggressive } \\
\text { behavior }\end{array}$ & Pearson correlation & 1,000 &,$- 453^{*}$ &, $487^{*}$ \\
\hline & Significance threshold values & 0,00 &, 547 &, 406 \\
\hline & Number & 5 & 4 & 5 \\
\hline Family type & Pearson correlation &,$- 453^{*}$ & 1,000 &,$- 964^{*}$ \\
\hline & Significance threshold values &, 547 & 0,00 &, 036 \\
\hline & Number & 4 & 4 & 4 \\
\hline Hostility inventory & Pearson correlation &, $487^{*}$ &,$- 964^{*}$ & 1,000 \\
\hline & Significance threshold values &, 406 &, 036 & 0,00 \\
\hline & Number & 5 & 4 & 7 \\
\hline
\end{tabular}

The values obtained by the subjects of our research in the "The self-esteem questionnaire" show us that these subjects have a low self-esteem of $44 \%$ and a very low self-esteem. $13 \%$.

There is a significant relationship between the aggressive behavior and self-esteem of the subjects $(\mathrm{r}=0.03, \mathrm{DF}=2, \mathrm{p}<0.001)$. The more the subjects have a more aggressive behavior, the lower the self-esteem, the aggression being more pronounced especially in the male subjects.

By applying the Lucher test, it shows more than an individual's reactions to existing situations and his general behavior gives a response-effect; it also indicates his ordinary conditioned attitude, his unconscious attitudes in the field of emotions, the will of action and aspiration, the impulses and needs buried deep in his psyche. Thus informed, the psychologist, psychiatrist or psychoanalyst can reach not only a complete and clear diagnosis, but also can know more easily which is the best course of action for remediation.

The color pairs chosen for this group mean that the subject "wants to be or have meaning" or "must be or have meaning". The largest share is the blue-black color group.

Choosing the pair of blue-green colors means that the subjects in this research need a sympathetic understanding of someone, which at the same time offers them recognition and approval. The courage in front of life and the tenacity are overloaded by the continuous attempt to overcome the existing difficulties; it maintains its objectives, but feels itself subject to intolerable pressure; considers that it is impossible to change the situation into one of mutual cooperation and trust and thus wishes to detach completely from it. 
The choice of the colors red and blue repressed the subjects' agitation, resulting from the attempt to resist any additional stimulation, combined with the inability to relax causes him to go beyond the capacity of his resources. He feels unable to do something to restore mutual affinity and trust and believes he is collapsed, in an unfortunate situation from which he cannot escape.

We find out about our subjects, by choosing the red-purple pair that manifests stress, resulting from frustrations in trying to achieve security and understanding. They are receptive to external stimuli, they want to live everything intensely but they find the existing situation quite frustrating. They need sympathetic understanding and a sense of security and are dissatisfied with his apparent ability to achieve his goals.

By choosing the pair of green-purple colors we find out about the subjects of our research that they are distrustful of others, they consider that they receive less than they deserve, realizing that they have to deal with things as well as they are.

The subjects of this research live with the feeling that they cannot do much about their problems and difficulties, which is due to the choice of the brown-green pair. Restrained emotions make it slightly offensive but they realize they have to deal with the circumstances as best they can. It can be said that our subjects did not trust them, which led them to choose the green-gray pair.

Choosing the black-and-white pair, we find out about the subjects of our research that they do not like the restrictions or limitations, they want to have the freedom to follow their own beliefs and principles, to control their own destiny.

From a physiological point of view our subjects show impatience and agitation, showing restraint in establishing affective relationships, demanding from the other total sincerity, all these things result from choosing the purple-gray pair.

It is clear from the choice of the black and white pair that the subjects of this research want to overcome the feeling of emptiness and live your life in all its aspects, avoiding any restrictions or limitations imposed on them.

From the application of "Draw a person", different interpretations emerge, such as: People drawn by the subjects of our research, $34 \%$ of them are drawn silhouettes with their legs apart and their hands raised, which tells us about the subjects who are keen for social affirmation, 19\% are drawn. moving, a fact that suggests about subjects that are dynamic and active and $27 \%$ of figures are inclined, so that we can say about subjects that are in a state of emotional imbalance or a feeling of fragility.

Drawing to the left of the page, as drawn by $35 \%$ of the subjects, means that they retreat into the past, fold themselves, taking the passive viewer position. Only $16 \%$ of our subjects, those who drew to the right of the page, are oriented to the future or to the world. $25 \%$ of the research subjects 
are either insecure and unadapted or feel without a solid anchor base in reality, needing power or expansion, the silhouettes they draw are drawn up or down the page.

Hatching means the desire to hide or disguise certain conflicting or irritating aspects of the self-image, which $39 \%$ of our subjects do and $41 \%$ have strong internal conflicts, a playful, mocking attitude, drawing strange things to them silhouettes strange things.

\section{Conclusions}

As can be seen from the research, from the interpretations and correlations made between the questionnaire "Self-esteem" applied to the group of subjects and "Inventory of hostility" confirms the hypothesis that low self-esteem leads to the manifestation of aggressive behavior, as well as the hypothesis according to to which, in the street children who manifest a high degree of social hostility, obvious aggressive components appear.

The analysis of the case studies shows that the subjects are aggressive, they want confirmation and social imposition, they are attached to the past and they are not anchored in reality only to a small extent, things confirmed by the results of the tests "Draw a person" and the test "Luscher" .

They often experience feelings of inferiority, trying to dominate through aggression. They need appreciation, I feel that they do not receive what they deserve.

By the presence of the bizarre elements, which appear in the human figures drawn by the subjects, it is indicated the existence of internal conflicts, a playful attitude, the display of a mask towards the others and of the masculinity, of the aggressiveness.

The street children feel that they cannot do much about their problems, their interest and enthusiasm are quickly aroused by the adventure, the unusual, the desire to live the moment.

\section{References}

[1] Adler, A., Psihologia şcolarului greu educabil, Ed. IRI, Bucureşti, 2006

[2] Birch, Ann Psihologia dezvoltării, Ed. Tehnică, Bucureşti, 2000,

[3] Cosmovici, A., lacob, L. ,Psihologie şcolară, Polirom, Iaşi, 1998,

[4] Killen, Kari Copilul maltratat, Imprimeria de vest R.A., Oradea, 1998,

[5] Mitrofan, N. ,Agresivitatea, în psihologia socială” Editura Polirom Iaşi, 1996

[6] Neamţu C. ,Devianţa şcolară, Editura Polirom Iaşi, 2003

[7] Ozunu, D., Psihopedagogia comportamentului normal şi deviant, Editura Genesis, ClujNapoca. ,1995. 
[8] Rus, M., Tasențe, T., Sandu, M. (2019). Study Regarding the Perception on the Personality Traits in Managerial Decision Making, Journal of Danubian Studies and Research, Vol 9, No $2(2019)$ 